5-ORIGINAL ARTICLES

\title{
Adjunctive Hyperbaric Oxygen Therapy promotes successful healing in patients with refractory Crohn's disease ${ }^{1}$
}

\author{
Marley Ribeiro Feitosa ${ }^{\mathrm{I}}$, Omar Féres Filho"I, Camila Mussolin TamakiII, Camila Perazzoli ${ }^{\mathrm{IV}}$, Mário Vinícius Angelete Alvarez \\ Bernardes $^{\text {, }}$ Rogério Serafim Parra ${ }^{\mathrm{VI}}$, José Joaquim Ribeiro da Rocha ${ }^{\mathrm{VII}}$, Omar Féres ${ }^{\mathrm{VIII}}$
}

DOI: http://dx.doi.org/10.1590/S0102-86502016001300005

${ }^{\mathrm{I}} \mathrm{MD}$, Division of Coloproctology, Department of Surgery and Anatomy, Ribeirão Preto Medical School, University of São Paulo. Conception and design of the study, acquisition of data, manuscript writing, manuscript review.

IIGraduate Student, Medical School of the Barão de Mauá University Center. Acquisition of data, manuscript review.

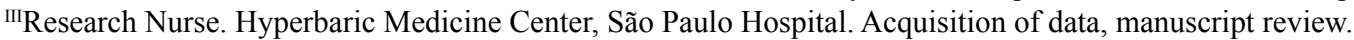

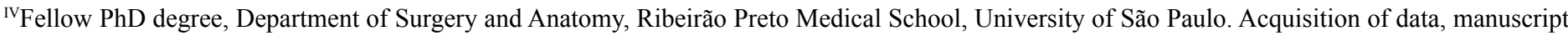
review.

vFellow PhD degree, Department of Surgery and Anatomy, Ribeirão Preto Medical School, University of São Paulo. Acquisition of data, manuscript review.

${ }^{\mathrm{VI}} \mathrm{MD}, \mathrm{PhD}$, Department of Surgery and Anatomy, Ribeirão Preto Medical School, University of São Paulo. Acquisition of data, manuscript review.

VIIPhD, Associate Professor, Head of Division of Coloproctology, Department of Surgery and Anatomy, Ribeirão Preto Medical School, University of São Paulo. Critical revising and final approval of the version to be published.

VIIIPhD, Associate Professor, Department of Surgery and Anatomy, Ribeirão Preto Medical School, University of São Paulo. Design of the study, acquisition of data, critical revising, final approval of the version to be published.

\section{ABSTRACT}

PURPOSE: To investigate de adjunctive effect of Hyperbaric Oxygen Therapy in a group of patients with refractory Crohn's disease. METHODS: A total of 29 subjects with refractory Crohn's disease were submitted to daily sessions of Hyperbaric Oxygen Therapy, in a 2800 Sechrist Monoplace Hyperbaric Chamber (Sechrist, USA) pressurized to 2.4 ATA. Each session lasted 2 hours. The endpoint was closure of enterocutaneous fistulas and complete healing of Pyoderma Gangrenosum and perineal Crohn's disease.

RESULTS: A total of 829 HBOT sessions were performed and no complications were noted. Overall success rate was $76 \%$ ( 22 cases). Pyoderma Gangrenosum and enterocutaneous fistulas had the highest successful healing rates ( $100 \%$ and $91 \%$, respectively). Perineal Crohn's disease healing rate was $65 \%$.

CONCLUSION: Adjunctive Hyperbaric Oxygen Therapy promoted satisfactory healing in a group of patients with refractory Crohn's disease.

Key words: Hyperbaric Oxygenation. Crohn Disease. Cutaneous Fistula. Pyoderma Gangrenosum. 


\section{Introduction}

Crohn's disease (CD) is a chronic inflammatory condition resulting from aberrant immune system activation. The disease primarily affects the gastrointestinal system but other organs may be involved ${ }^{1}$.

Clinical manifestations are heterogeneous and may vary from mild cases (abdominal pain, changes in bowel habit and weight loss) to serious complications such as acute abdomen, perineal sepsis, fistulizing disease and colorectal cancer. The course of the disease is usually relapsing but some individuals may experience continuous inflammation ${ }^{2}$.

Since CD cannot be cured, most treatment options aim the induction and maintenance of remission by controlling inflammation. Surgery is usually recommended for non-responsive or complicated cases ${ }^{3}$.

Some studies have shown benefits of hyperbaric oxygen therapy (HBOT) especially in the treatment of complex perineal wounds, pyoderma gangrenosum (PG) and fistulizing disease $\mathrm{e}^{4-8}$. HBOT is a treatment modality that consists in $100 \%$ oxygen breathing in pressurized chambers. The improvement with HBOT is attributed to local events (such as neovascularization and reduced hypoxia, stem cell mobilization/differentiation and extracellular matrix formation) and systemic effects (decrease in proinflammatory cytokines and biomarkers of oxidative stress $)^{9-11}$.

The purpose of this study was to evaluate the adjunctive effect of HBOT in a group of patients with of pharmaco-refractory perineal Crohn's disease (PCD), enterocutaneous fistulas (ECF) and PG.

\section{Methods}

\section{Patients}

A prospective institutional review board-approved study was conducted at Clinics Hospital-University of São Paulo
(Ribeirão Preto, SP, Brazil). A total of 29 patients with pharmacorefractory $\mathrm{CD}$ associated with $\mathrm{ECF}, \mathrm{PCD}$ or $\mathrm{PG}$ were selected to HBOT, from 2008 to 2015. An informed written consent was provided in all cases. Hyperbaric sessions were performed at Hyperbaric Medicine Center-São Paulo Hospital (Ribeirão Preto, SP, Brazil) that keeps a prospective, database of all sessions.

\section{Hyperbaric oxygen therapy}

Daily HBOT sessions were performedin a 2800 Sechrist Monoplace Hyperbaric Chamber (Sechrist, USA) pressurized to 2.4 ATA and lasted 2 hours, each. The number of sessions was not constant and varied according to the clinical outcome of patients in order to obtain the best results. Basic care of chronic cutaneous lesions was maintained throughout the entire treatment and included cleaning and dressings, antibiotics and surgical debridement when needed. The result of HBOT was classified as satisfactory or unsatisfactory, when improvement could not be noted.

\section{Results}

The most common indication for HBOT was PCD $(n=15$ / 51.7\%) followed by ECF ( $\mathrm{n}=8 / 27.5 \%)$ and PG $(\mathrm{n}=3 / 10.3 \%)$. An association between ECF and PCD was noted in $1(3.5 \%)$ case. Concomitant ECF and PG were found in 1 (3.5\%) patient. One patient $(3.5 \%)$ exhibited all three complications. Table 1 summarizes some of the patients and treatment characteristics.

The median number of sessions was 20 (range, 10-86). A total of 829 HBOT sessions were performed and no complications were noted. Overall success rate was $76 \%$ (22 cases). Figure 1 illustrates some cases before and after HBOT. PG and ECF had the highest successful healing rates ( $100 \%$ and $91 \%$, respectively). PCD completely healed in $65 \%$ of the cases. The remaining patients had an unsatisfactory response and needed major surgery surgeries (intestinal diversion with proctectomy or abdominalperineal amputation of the rectum). 
TABLE 1 - Main characteristics of patients and treatment.

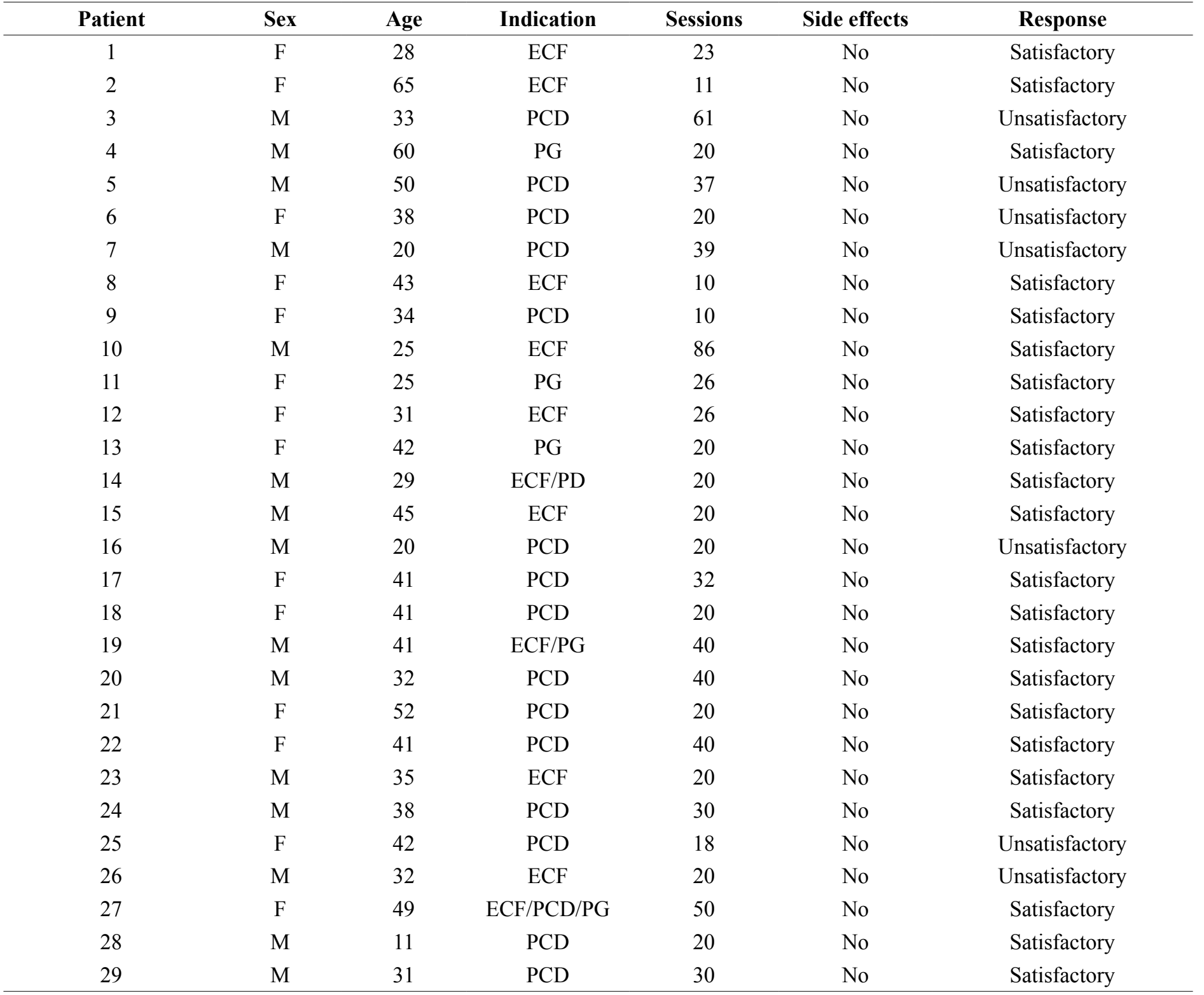

ECF: enterocutaneous fistula, PCD: perineal Crohn's disease, PG: pyoderma gangrenosum 


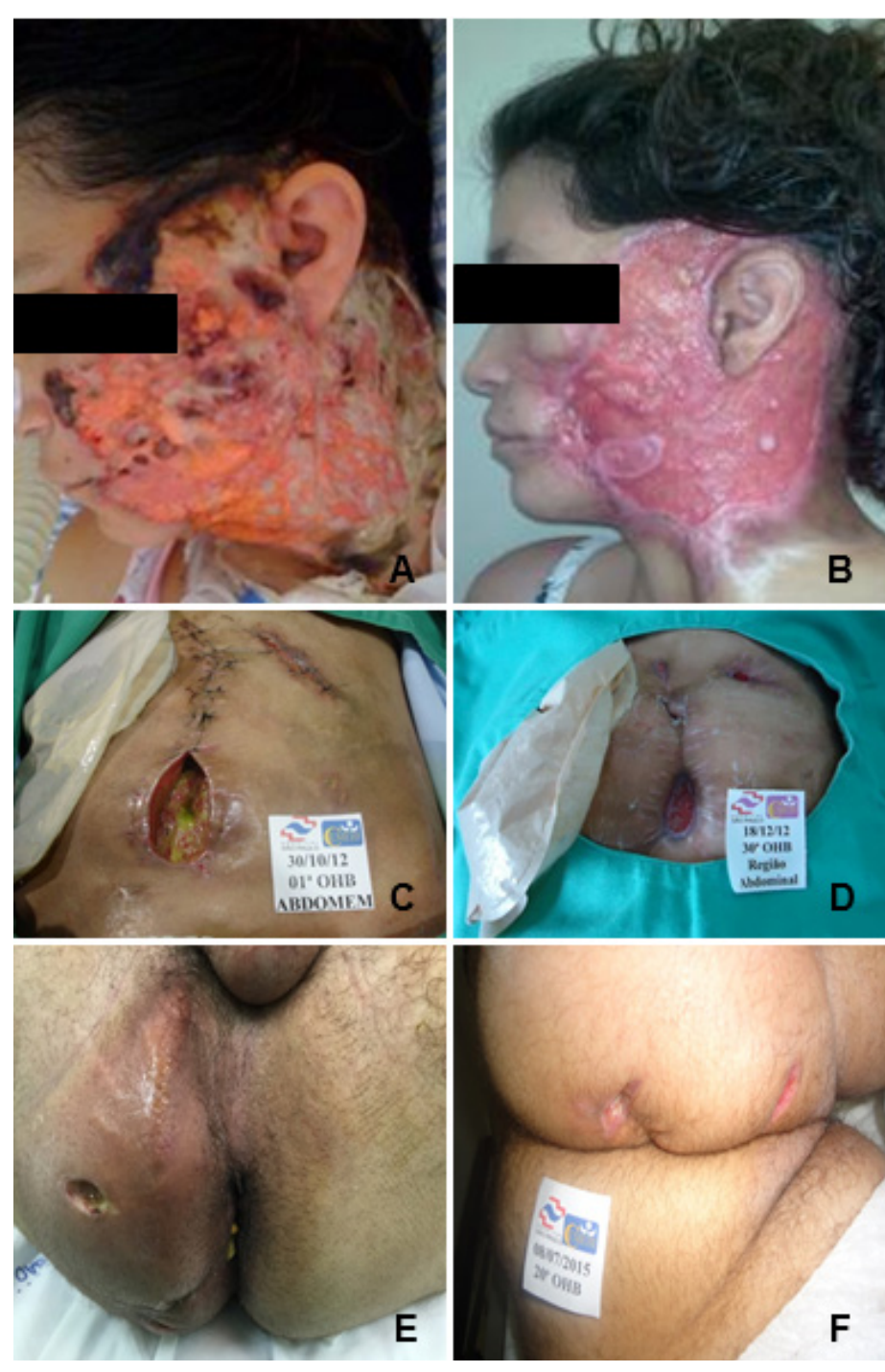

FIGURE 1 - Patients submitted to Hyperbaric Oxygen Therapy. First row: facial Pyoderma Gangrenosum before (A) and after 30 sessions (B). Second row: low-output enterocutaneous fistula before (C) and after 30 sessions (D) evidencing ongoing healing of the abdominal wound and complete fistula closure. Third row: Infected perineal Crohn's disease submitted to seton procedure and abscess drainage (E) evidencing reduction of edema and no infection after 30 sessions (F).

\section{Discussion}

The complete pathogenesis of CD is unclear. Animal models of colitis have shown that intestinal hypoxia may be observed as inflammation aggravates ${ }^{12}$. This hypoxic microenvironment, in thus, is a potent stimulus to further inflammation and apoptosis via increasesin hypoxia-inducible transcription factor (HIF) levels ${ }^{13}$ This state of perpetual inflammation can be halted by increases in tissue oxygenation ${ }^{14}$. Measurements of oxygen tension on perineal wounds may exhibit increases up to 35 times after HBOT $^{15}$.

Perianal disease can be found in up to $35-45 \%$ of CD patients. Anorectal abscesses, fissures and fistulas are the most common findings ${ }^{16}$. Appropriate treatment involves the use of symptomatic medication, local care (cleansing and sitz baths), antibiotic therapy and immunomodulators in some cases ${ }^{17-21}$. Surgery is usually recommended for resistant or complex perineal wounds. Care should be taken to avoid extensive damage since poor healing may be found, specially if severe proctitis is present ${ }^{22}$.

Reported response rate for perineal disease treated in regimens of hyperoxygenation range from $75-100 \%{ }^{4-8}$. In the present study, complete healing of PCD was obtained in the majority of patients. Although minor surgical procedures were necessary to remove devitalized tissues and control infection, no intestinal diversion or proctectomy was necessary in the group that responded to HBOT.

The effects of HBOT in complex wounds include: decreased inflammation and tissue edema, mobilization of steam cells, neovascularization, fibroblasts growth and extracellular matrix formation ${ }^{23-26}$. Those changes in wound microenvironment are powerful stimuli towards healing and could explain some of the results found in CD patients with complex wounds. The same rationale could be used to explain the pain relief, systemic corticosteroids reduction and accelerated healing in $\mathrm{PG}$ patients ${ }^{27}$.

The use of HBOT in enterocutaneous fistulas may be appropriate if output volume is low. Complicated Fistulas with higher debit, chronic course, labiate, with satellite collection and distal obstruction may have an initial conservative approach; yet, surgery isusually the definite treatment ${ }^{28}$. In the present study, treatment of ECF with HBOT was considerate excellent; however, patients were evaluated immediately after the HBOT sessions and there is no long-term follow-up. Healing failure was found in only one patient with a chronic fistula of high output volume. This successful healing rate may be explained by the systemic antinflammatory properties of $\mathrm{HBOT}^{12}$.

The results of this research are encouraging sincepatients who were refractory to maximum medical treatment obtained high healing rates; however, the small number of patients, the short-term follow-up and the lack of a control group limitour conclusions. Part of the good results could be explained by the close monitoring of patients that included daily clinical evaluations, intensive wound care and optimization of medical therapy. A prospective controlled study could solve this problem; yet, it would be ethically questionable to create a control group and deny a possibility of treatmentin patients with an aggressive condition and limited therapeutic options. This pattern of limitation is shared by most studies that deal with HBOT in severe/refractory CD. The authors believe that a randomized controlled trial with HBOT in CD patients in earlier stages of disease is necessary and will contribute to reduce biases. 


\section{Conclusion}

A high healing rate was observed in a group of patients with complicated and refractory $\mathrm{CD}$ after HBOT. No complications were found during the procedure. The results suggest that HBOT may have an adjunctive role in $\mathrm{CD}$ complications. Further investigation is necessary to strengthen our findings.

\section{References}

1. Sands BE. From symptom to diagnosis: clinical distinctions among various forms of intestinal inflammation. Gastroenterology. 2004;126(6):1518-32.PMID: 15168364.

2. Henriksen M, Jahnsen J, Lygren I, Aadland E, Schulz T, Vatn MH, Moum B. Clinical course in Crohn's disease: results of a five-year population-based follow-up study (the IBSEN study). Scand J Gastroenterol. 2007;42(5):602-10.PMID: 17454881.

3. Lichtenstein GR, Hanauer SB, Sandborn WJ. Management of Crohn's disease in adults. The American journal of gastroenterology. 2009;104(2):465-83.PMID: 19174807.

4. Iezzi LE, Feitosa MR, Medeiros BA, Aquino JC, Almeida AL, Parra RS, Rocha JJ, Feres O. Crohn's disease and hyperbaric oxygen therapy. Acta Cir Bras. 2011;26(2):129-32.PMID: 22030829.

5. Lavy A, Weisz G, Adir Y, Ramon Y, Melamed Y, Eidelman S. Hyperbaric oxygen for perianal Crohn's disease. J Clin Gastroenterol.1994;19(3):202-5.PMID: 7806829.

6. Colombel JF, Mathieu D, Bouault JM, Lesage X, Zavadil P, Quandalle P, Cortot A. Hyperbaric oxygenation in severe perineal Crohn's disease. Dis Colon Rectum. 1995;38(6):609-14.PMID: 7774472 .

7. Fraser GM, Niv Y. Six patients whose perianal and ileocolic Crohn's disease improved in the Dead Sea environment. J Clin Gastroenterol.1995;21(3):217-9.PMID: 8648056.

8. Weisz G, Lavy A, Adir Y, Melamed Y, Rubin D, Eidelman S, Pollack S. Modification of in vivo and in vitro TNF-alpha, IL-1, and IL-6 secretion by circulating monocytes during hyperbaric oxygen treatment in patients with perianal Crohn's disease. J Cin Immunol. 1997;17(2):154-9.PMID: 9083891.

9. Hopf HW, Gibson JJ, Angeles AP, Constant JS, Feng JJ, Rollins MD, Zamirul-Hussain M, Hunt TK. Hyperoxia and angiogenesis. Wound Repair Regen. 2005;13(6):558-64.

10. Fosen KM, Thom SR. Hyperbaric oxygen, vasculogenic stem cells, and wound healing. Antioxid Redox Signal. 2014;21(11):1634-47. PMID: 16283871.

11. Benson RM, Minter LM, Osborne BA, Granowitz EV. Hyperbaric oxygen inhibits stimulus-induced proinflammatory cytokine synthesis by human blood-derived monocyte-macrophages. Clin Exp Immunol. 2003;134(1):57-62.PMID: 12974755.

12. Parra RS, Lopes AH, Carreira EU, Feitosa MR, Cunha FQ, Garcia SB, Cunha TM, Rocha JJ, Feres O. Hyperbaric oxygen therapy ameliorates TNBS-induced acute distal colitis in rats. Med Gas Res. 2015;5:6.PMID:25926972.

13. Carmeliet P, Dor Y, Herbert JM, Fukumura D, Brusselmans K, Dewerchin M, Neeman M, Bono F, Abramovitch R, Maxwell P, Koch CJ, Ratcliffe P, Moons L, Jain RK, Collen D, Keshert E. Role of HIF-1alpha in hypoxia-mediated apoptosis, cell proliferation and tumour angiogenesis. Nature. 1998;394(6692):485-90.PMID: 9697772.

14. Goldman RJ. Hyperbaric oxygen therapy for wound healing and limb salvage: a systematic review. PM R. 2009;1(5):471-89.PMID: 19627935.

15. Brady CE 3rd, Cooley BJ, Davis JC. Healing of severe perineal and cutaneous Crohn's disease with hyperbaric oxygen. Gastroenterology. 1989;97(3):756-60.PMID: 2753335.

16. Rankin GB, Watts HD, Melnyk CS, Kelley ML Jr. National Cooperative Crohn's Disease Study: extraintestinal manifestations and perianal complications. Gastroenterology. 1979;77(4 Pt 2):91420.PMID: 467943

17. Loffler T, Welsch T, Muhl S, Hinz U, Schmidt J, Kienle P. Long-term success rate after surgical treatment of anorectal and rectovaginal fistulas in Crohn's disease. Int J Colorectal Dis. 2009;24(5):521-6. PMID: 19172284.

18. Bernstein LH, Frank MS, Brandt LJ, Boley SJ. Healing of perineal Crohn's disease with metronidazole. Gastroenterology. 1980;79(2):357-65.PMID: 7399243.

19. Dejaco C, Harrer M, Waldhoer T, Miehsler W, Vogelsang H, Reinisch W. Antibiotics and azathioprine for the treatment of perianal fistulas in Crohn's disease. Aliment Pharmacol Ther. 2003;18(11-12):111320.PMID: 14653831.

20. Kotze PG, Albuquerque IC, Moreira Ada L, Tonini WB, Olandoski M, Coy CS. Perianal complete remission with combined therapy (seton placement and anti-TNF agents) in Crohn's disease: a Brazilian multicenter observational study. Arq Gastroenterol. 2014;51(4):284-9.PMID: 25591155.

21. Bouguen G, Siproudhis L, Gizard E, Wallenhorst T, Billioud V, Bretagne JF, Bigard MA, Peyrin-Biroulet L. Long-term outcome of perianal fistulizing Crohn's disease treated with infliximab. Clin Gastroenterol Hepatol. 2013;11(8):975-81.PMID: 23376316.

22. Singh B, George BD, Mortensen NJ. Surgical therapy of perianal Crohn's disease. Dig Liver Dis. 2007;39(10):988-92.PMID: 17723322 .

23. Kang TS, Gorti GK, Quan SY, Ho M, Koch RJ. Effect of hyperbaric oxygen on the growth factor profile of fibroblasts. Arch Facial Plast Surg. 2004;6(1):31-5.PMID: 14732642.

24. Aggarwal S, Pittenger MF. Human mesenchymal stem cells modulate allogeneic immune cell responses. Blood. 2005;105(4):1815-22. PMID: 15494428.

25. Helmers R, Milstein DM, van Hulst RA, de Lange J. Hyperbaric oxygen therapy accelerates vascularization in keratinized oral mucosal surgical flaps. Head Neck. 2014;36(9):1241-7.PMID: 23913629.

26. Jung S, Wermker K, Poetschik H, Ziebura T, Kleinheinz J. The impact of hyperbaric oxygen therapy on serological values of vascular endothelial growth factor (VEGF) and basic fibroblast growth factor (bFGF). Head Face Med. 2010;6:29.PMID: 21176170.

27. Vieira WA, Barbosa LR, Martin LM. Hyperbaric oxygen therapy as an adjuvant treatment for pyoderma gangrenosum. An Bras Dermatol. 2011;86(6):1193-6.PMID: 22281912.

28. Sampietro GM, Casiraghi S, Foschi D. Perforating Crohn's disease: conservative and surgical treatment. Dig Dis. 2013;31(2):218-21. PMID: 24030229.

\section{Correspondence:}

Marley Ribeiro Feitosa

Av. Bandeirantes, 3900 - Campus Universitário - Monte Alegre - $9^{\circ}$ andar 14048-900 - Ribeirão Preto, São Paulo, Brasil

Tel.: (55 16) 3602-2593

marleyfeitosa@yahoo.com.br

Conflict of interest: none

Financial source: none

${ }^{1}$ Research performed at the Division of Coloproctology, Department of Surgery and Anatomy, Ribeirão Preto Medical School, University of São Paulo. 